\title{
Enlightening Europe on Islam and the Ottomans: Mouradgea d'Ohsson and His Masterpiece. Carter Vaughn Findley (Leiden: Brill, 2019) Pp. 410. $\$ 90.00$ cloth. ISBN: 9789004363120 - Corrigendum
}

Virginia Aksan

DOI: https://doi.org/10.1017/S0020743821000544; Published online by Cambridge University Press 15 September 2021

In the initial publication of Aksan (2021), Carter Vaughn Findley's name was printed incorrectly in the title of the book review. The original review has been updated to reflect the author's correct name.

The reviewer apologizes for this error.

\section{Reference}

Aksan, Virginia. “Enlightening Europe on Islam and the Ottomans: Mouradgea D’Ohsson and His Masterpiece. Carter Vaughn Findley (Leiden: Brill, 2019) Pp. 410. \$90.00 Cloth. ISBN: 9789004363120.” International Journal of Middle East Studies 53, no. 3 (2021): 553-55. doi:10.1017/S0020743821000544.

\footnotetext{
Cite this article: Aksan V (2021). Enlightening Europe on Islam and the Ottomans: Mouradgea d'Ohsson and His Masterpiece. Carter Vaughn Findley (Leiden: Brill, 2019) Pp. 410. \$90.00 cloth. ISBN: 9789004363120 - Corrigendum. International Journal of Middle East Studies 53, 731-731. https://doi.org/10.1017/S0020743821001070

(c) The Author(s), 2021. Published by Cambridge University Press
} 